\title{
ARTICLE
}

\section{ICING PHENOMENA FOR MANAGED AQUIFER RECHARGE (MAR) AND IT'S FEFLOW SIMULATION RESULT}

\author{
Nasanbayar $N$. *
}

Environmental Engineering department, School of Civil engineering and Architecture Mongolian University of Science and Technology, Ulaanbaatar, Mongolia

\begin{abstract}
Ulaanbaatar, the capital of Mongolia, shows a highly dynamic urban and industrial development, with a strong increase of population. Thus, water demand is continuously rising while water availability is in general low and less reliable.

The semi-arid and cold environment shows a high variability in precipitation and river discharge, with a general tendency towards decreasing water availability due to increasing air temperatures and thus rising potential evaporation.

In parallel with the city's development, the extended groundwater aquifer shows a clear decline, and the groundwater levels drop significantly. Therefore, a groundwater management system based on managed aquifer recharge is proposed and a strategy to implement these measures in the Tuul valley is presented.

In this study considered enhancement of natural recharge rates during the early winter cold period, an increase of groundwater recharge through creating ice storages, due to keep water source as in ice form on surface. In dry season March to May ice storage recharge surface and groundwater by melting where Tuul River is non-flow condition. In this paper also written matlab icing code in water supply wells location, limited and unlimited area.

The study of icing was processed in feflow simulation scenarios for artificially recharging groundwater resources.

In this study considered feflow simulation scenarios for artificially recharging groundwater resources like enhancement of natural recharge rates during the early winter cold period, an increase of groundwater recharge through creating ice storages, due to keep water source as in ice form on surface, drainage canal recharging aquifer from opposite side, constructing underground dam that accumulates groundwater behind. The result shown that one of the possibilities recharge groundwater in dry season is icing method which creates ice sheets over ice and build ice storages in winter, keep water in ice form.
\end{abstract}

Keywords: Ulaanbaatar; Ice storage; Managed Aquifer recharge; 
The Tuul River flows through Mongolia's capital along the borderline of the Siberian Taiga forest and semi-arid steppe lands of central Asia near Ulaanbaatar. The water level of the Tuul River fluctuates according to annual high-flow to low-flow cycles, with its average water flow being $26,6 \mathrm{~m} 3 / \mathrm{s}$ [5]. It also feeds the aquifer that providing Ulaanbaatar's water supply.

The groundwater aquifer located near Ulaanbaatar capital city of Mongolia, is the only source of water supply and it is important to ensure that groundwater is available now and for the future.[10][28]. The main watercourse near the city is the Tuul River, fed by precipitation in the nearby Khentii Mountains.
However, due to the absence of precipitation during winter and spring, the riverbed usually runs dry during that time, and observations show that the dry period has been extending within the last years.[11]. Since many decades, the water supply of Ulaanbaatar is exclusively based on the use of groundwater in the Tuul valley. [9]

A small river like Tuul frozen to the bed and in the end of April has not ice cover and some places is dry bed without flow. The origin of the Tuul river in highly mountains over $2500 \mathrm{~m}$ oversee level but Ulaanbaatar city lies in altitude $1300 \mathrm{~m}$. In April the mountains where is origin of the river still cold and nonmelting season for ice and snow but in city region river ice cover breaks up and non-flow condition.
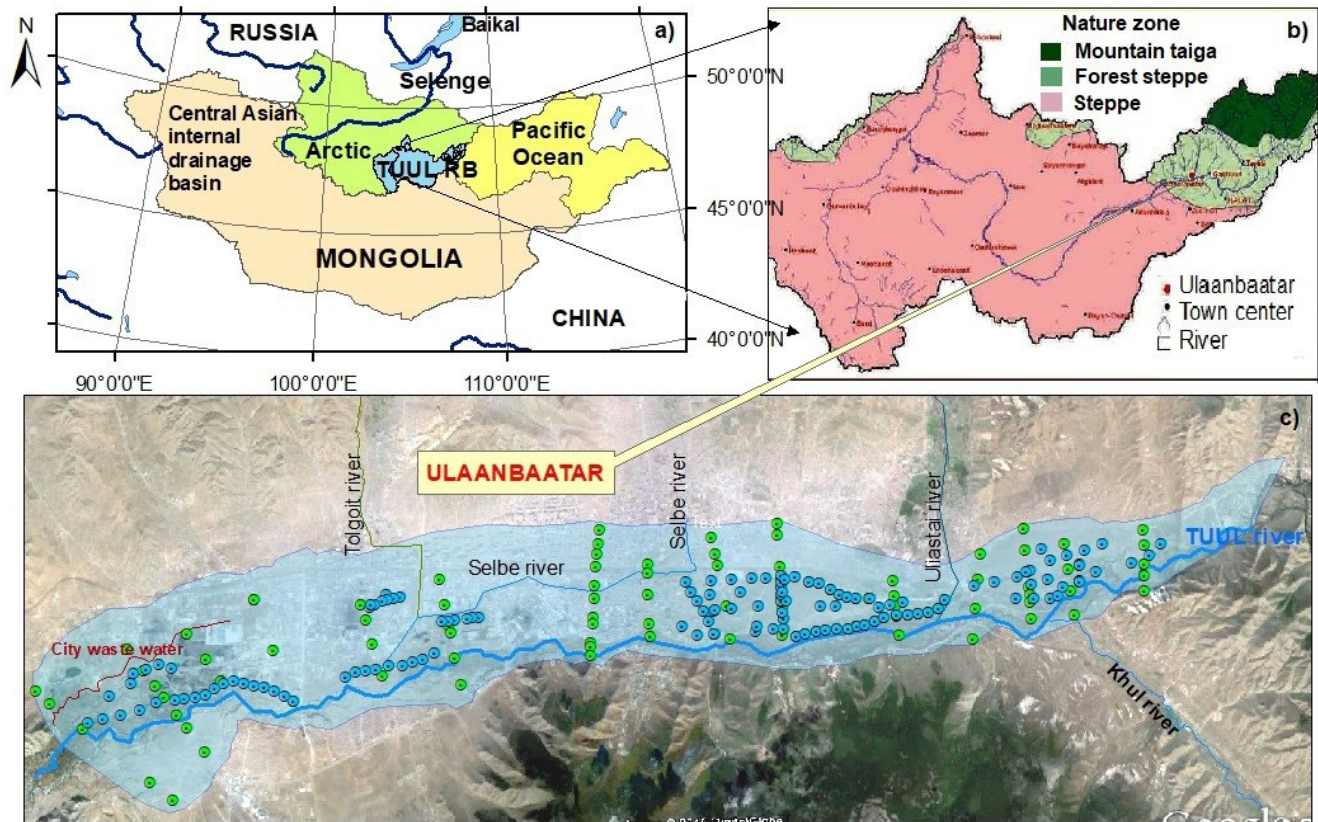

\section{Legend}
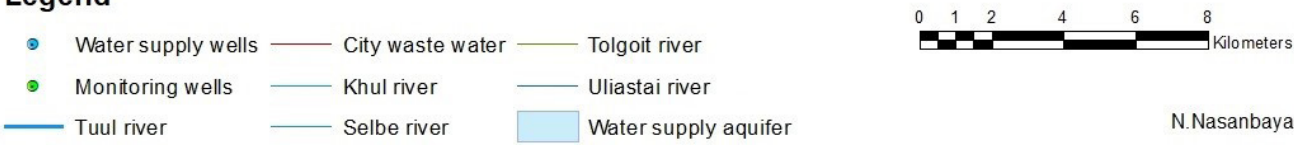

Figure 1. Groundwater aquifer south side of Ulaanbaatar city

a) Mongolian hydrological drainage basins; b) Tuul River basin; c) UB aquifer 
The icing phenomena is one of the most important parameters for semi-arid, highly continental climate condition and plays significant role in hydrological cycle and regime(Batima Punsalmaa, (2004)),[2])in Mongolia. The ice cover of rivers and lakes plays cold season for icing continues five to six Months and ice cover thicknesses reaches 0.8 to 3.2 meters. However, some mountains big rivers with more slope and bigger perturbation boulders in riffle section stayed open whole year do not completely freeze along the length.

The average date of first ice occurrence on rivers is third week of October. The freezing of the rivers continues from the end of October to third and last week of November. The ice cover duration averages 145 days. During the last 60 years, the annual mean air temperature in Mongolia has increased $1.66^{\circ} \mathrm{C}$ with winter temperature increasing $3.61^{\circ} \mathrm{C}$, spring-autumn temperature $1.4-1.5^{\circ} \mathrm{C}$, [2] and summer with no clear trend. Temperature has increased rapidly in the March, May, September and November and therefore the ice regimes of the Mongolian rivers has changed.

Ice phenology has shifted by 3-30 days in

\section{MATERIALS AND METHODS}

\section{Aufeis - Icing process in Mongolia}

The Uliastai River one of the tributaries Tuul River originates from Khentii mountains flows from north east side to south through Ulaanbaatar city contributes Tuul River in area where water supply wells of Central source for Ulaanbaatar city.

Icing - Aufeis accumulates during winter along streams and river valley in northern Mongolia where dominates semi-arid, highly continental regions environments. Here in Uliastai River build ice from the middle of terms of freeze-up and break-up dates and ice cover duration has shortened. Maximum ice thickness has also decreased from the 1960's to 2000.[2])

Ice begins to form when water is cooled to $00 \mathrm{C}$ and continues to lose heat. When heat content reaches the heat of fusion of water $3.34 * 10^{5} \mathrm{Jkg}^{-1}$ ice begins to form. [1]

Generally, for a surface ice cover to become firmly established, the mean (depthaveraged) temperature of water must be less than $2^{\circ} \mathrm{C}$, the daily average temperature must be less than $-5^{\circ} \mathrm{C}$, and the wind speed must be less than $5 \mathrm{~m} / \mathrm{s}$ [1].

In dry season near Ulaanbaatar area Tuul River dried out no water there because whole winter pumped groundwater for city water supply consumption. Therefore, icing or ice storage helps as to store water source in ice form on surface near city in winter and in dry season would be recharge surface and groundwater by melting.

The icing code written in this paper used for FEFLOW simulation for a recharge groundwater as a source of a water by melting.

October until end of December and melting process starting from end of March until end of April.

The icing dynamics depending on more from groundwater fluxes, that discharges alongside of main channel. This side spring build ice sheets over frozen riverbed, where mainstream flows under ice cover. We are studied ice generating process and icing dynamics from middle of October to end of December 2017. Table 1. 
Table 1. Measured discharge data and ice thicknesses

\begin{tabular}{|c|c|c|c|c|c|c|c|}
\hline \multirow{2}{*}{ № } & \multirow{2}{*}{$\begin{array}{l}\text { Date } \\
2017\end{array}$} & \multicolumn{2}{|c|}{ location coordinate } & \multirow{2}{*}{$\begin{array}{c}\text { discharge } \\
{[1 / \mathrm{s}]}\end{array}$} & \multirow{2}{*}{$\begin{array}{l}\text { icing } \\
\text { start }\end{array}$} & \multirow{2}{*}{$\begin{array}{c}\text { ice }[\mathrm{cm}] \\
\text { thick }\end{array}$} & \multirow{2}{*}{ report } \\
\hline & & $\mathrm{N}$ & $\mathrm{E}$ & & & & \\
\hline 1 & 06. Oct & $47^{0} 55^{\prime} 18,89^{\prime \prime}$ & $107^{0} 01 ' 10,78^{\prime \prime}$ & 5.4 & 13.Oct & 23 & \\
\hline 2 & 06. Oct & $47^{0} 55^{\prime} 18,56^{\prime \prime}$ & $107^{0} 01 ' 04,83^{\prime \prime}$ & 3.8 & 13.Oct & 36 & \\
\hline 3 & 06. Oct & $47^{0} 55^{\prime} 18,67^{\prime \prime}$ & $107^{0} 01^{\prime} 02,733^{\prime \prime}$ & 1.6 & 13.Oct & 8 & \\
\hline 4 & 06. Oct & $47^{0} 55^{\prime} 20,08^{\prime \prime}$ & $107^{\circ} 00^{\prime} 56,28^{\prime \prime}$ & 41 & 15.Dec & 50 & \\
\hline 5 & 06. Oct & $47^{0} 55^{\prime} 20,24 ”$ & $107^{0} 00^{\prime} 56,42^{\prime \prime}$ & 40.5 & 15.Dec & 50 & \\
\hline 6 & 06. Oct & $47^{0} 55^{\prime} 22,96^{\prime \prime}$ & $107^{\circ} 00^{\prime} 44,06 "$ & 42 & 03. Nov & 20 & \\
\hline 7 & 06. Oct & $47^{0} 55^{\prime} 29,22^{\prime \prime}$ & $107^{0} 00^{\prime} 44,41^{\prime \prime}$ & 13,4 & 10.Nov & 10 & \\
\hline 8 & 06. Oct & $47^{0} 55^{\prime} 29,10^{\prime \prime}$ & $107^{\circ} 00^{\prime} 46,18^{\prime \prime}$ & 11.4 & & & Spring \\
\hline 9 & 06. Oct & $47^{0} 55^{\prime} 55,60 ”$ & $107^{0} 01 ' 16,07^{\prime \prime}$ & 42 & 10.Nov & 10 & \\
\hline 10 & 06. Oct & $47^{0} 55^{\prime} 51,57^{\prime \prime}$ & $107^{0} 01^{\prime} 09,76^{\prime \prime}$ & 37 & 10.Nov & 12 & \\
\hline 11 & 06. Oct & $47^{0} 55^{\prime} 17,00^{\prime \prime}$ & $107^{0} 01^{\prime} 25,21^{\prime \prime}$ & 1.88 & 13.Oct & 5 & \\
\hline 12 & 06. Oct & $47^{0} 55^{\prime} 16,74 ”$ & $107^{0} 01^{\prime} 27,76^{\prime \prime}$ & 882 & 01. Dec & 20 & Uliastai \\
\hline 13 & 19.Nov & $47^{0} 56^{\prime} 17,30^{\prime \prime}$ & $107^{0} 01^{\prime} 32,73^{\prime \prime}$ & 32 & 10. XI & 0 & rigth stream \\
\hline 14 & 26.Nov & $47^{0} 56^{\prime} 17,30^{\prime \prime}$ & $107^{0} 01^{\prime} 32,73^{\prime \prime}$ & 28.8 & 10. XI & 13 & right tream \\
\hline 15 & 01.Dec & $47^{0} 56^{\prime} 16,79^{\prime \prime}$ & $107^{0} 01 ' 36,73$ ' & 146.4 & 03. XI & 20 & left stream \\
\hline 16 & 08.Dec & $47^{0} 56^{\prime} 16,79^{\prime \prime}$ & $107^{0} 01^{\prime} 36,73^{\prime \prime}$ & 146.4 & 03. XI & 70 & left stream \\
\hline 17 & 15.Dec & $47^{0} 56^{\prime} 17,30^{\prime \prime}$ & $107^{0} 01^{\prime} 32,73^{\prime \prime}$ & under ice & 03. XI & 45 & right tream \\
\hline
\end{tabular}

The mainstream is flowing by main riverbed under ice cover but alongside spring stream is creating ice on the top of frozen ice sheets. This phenomenon calls icing or Aufeis. Icing - Aufeis are sheets of stratified ice formed by freezing consecutive water leaks. [8]

The water flows over existing ice layers. It forms by upwelling of by ground-water discharge or manmade drainage channels where groundwater discharge is blocked by ice, perturbing the steady-state condition and causing a small incremental rise in the local water table until discharge occurs along the bank and over the top of the previously formed ice.

In the beginning of October where river flow freeze from side benches, the springs which no longer have extending energy, freeze first. When the river freezes completely and forms an ice cover the spring leaks from under the ice or ice hummock with increased groundwater head and pressure.

The river flow under the ice cover is pressurised therefore the side springs and groundwater take the same additional head and energy.

It is quite difficult to determine the point of leakage from under the ice cover because pressurized groundwater build ice hummocks some of which have leakage water but some of them stay without discharge.

Groundwater flux coming out on the surface like a spring water, creates ice tops next to the ice sheet which fills the lower ravines and smoothens also the horizontal ice sheet. When the air temperature starts dipping below $0^{\circ} \mathrm{C}$ 
the process of non-flow water freezing begins. After the average daily temperature drops below $-5^{\circ} \mathrm{C}$ streams and rivers that are flowing begin to freeze from the bench sides.[2] .

On 7 November 2017 daily air temperature average decreased under $-10^{\circ} \mathrm{C}$ and thus influenced completely ice cover small streams. (See appendixes Table 3). The hourly temperature measurement from first of November to end of December 2017 demonstrated in the following Table 3.

The groundwater flux alongside of the river drains through drainage canal built icing phenomena while springs flow bed blocked by ice and mainstream in main riverbed flows under ice cover.

In this section, the Uliastai River almost becomes like a spring, where nearly a third of the river discharge filtrates into the groundwater and the groundwater leaks out like a spring.

Thus, phenomena create side springs leakage from under frozen soil which flows over frozen soil and ice cover streams, fills ravines and lower lands, creates ice sheet on the ice until river valley would be even same horizon. After that, when the average daily temperature drops below $-20^{\circ} \mathrm{C}$ the discharge of both the head and pressure of groundwater leakage also decreases, which means that the groundwater flux do not come out over the surface, for they stay underground.

The ice thickness measurements from 15 and 30 December show that the thickness of Aufeis sheets not increased.

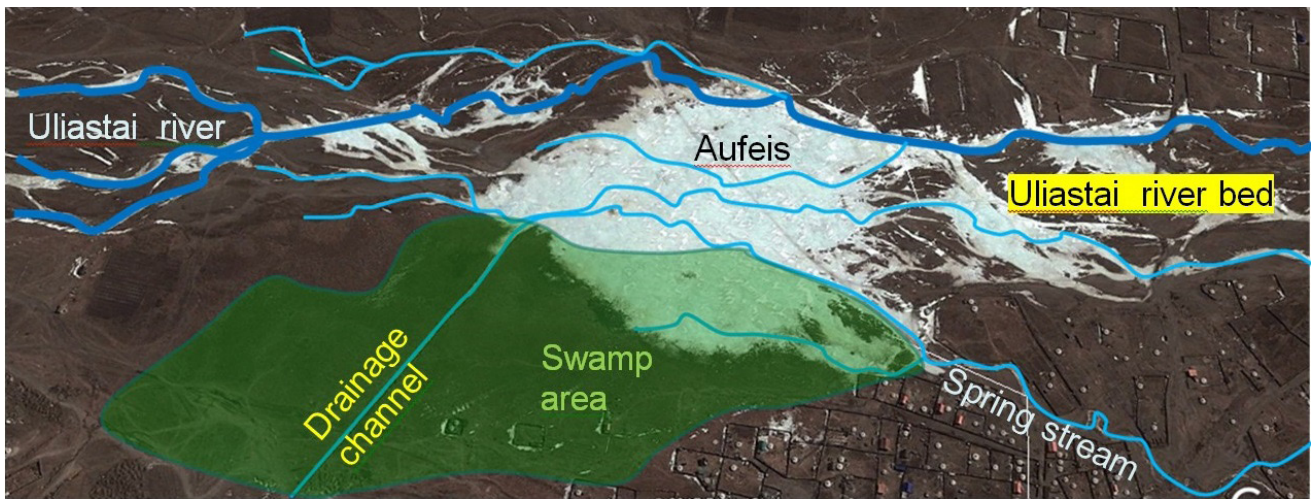

Figure 2. Icing dynamic process in Uliastai River valley

Such a way groundwater leakage like drained water or springs over frozen soil and ice cover create stratified ice sheets over ice sheets. Here in Uliastai River spring discharge $32 \mathrm{l} / \mathrm{s}$ small amount of water but it built ice thicknesses in some place until $1 \mathrm{~m}$ thick. Some of the rivers make ice sheets to several meters thick. The end of Aufeis built depends on discharge of Springs and quantity of Aufeis building river flow usually last decade days of December or first decade days of January where after longest December night begin colder days of the year. A bigger river such as Tuul is possible to create Aufeis until February. Aufeis typically melts out during summer until end of April sometimes beginning of May and will often form in the same place year after year [8]. We are measuring ice thickness every year and it's show almost same results.

\section{Aufeis-Icing formation code}

The aufeis formation of groundwater flux out coming from ground like spring creates such a way ice accumulation over frozen soil and ice, sheet by sheet until leakage water would block by ice due to groundwater pressure and energy not enough to spreading over ice layers. Thus, aufeis thickness depends on air temperature fluctuation and discharge quantity of springs. 
The matlab code of ice formation is written at the Tuul River valley on water supply source area's upper A-A zone. Drainage canal with gravel sole structure has been taken into consideration, which derivates groundwater flux from the Tuul River and a leakage spring with discharge $0.5 \mathrm{~m}^{3} / \mathrm{s}$ is generating the aufeis phenomena on an unlimited area.

The 1 mole of water and its dimension convert give follows:

Volume $=18$ grams; 1 gram $=1 \mathrm{~mL}$;

Volume $=18 \mathrm{~mL}$ holds a mole of water.

$18 \mathrm{~mL}$ is the volume of water like small Ping-Pong ball. 1 liter is $1 \mathrm{dm}^{3}$.

$18 \mathrm{~mL}=18.0152 \mathrm{~cm}^{3}=18.0152 \mathrm{ml}=2.62 * 2.62 * 2.62 \mathrm{~cm}^{3}$.

When $1 \mathrm{~m}^{3}$ water spread by $1 \mathrm{~mol}$ sheet then would be

$1000000 \mathrm{gram} / 18.0152=55500 \mathrm{~mol} * 0.0262 \mathrm{~m} / \mathrm{mol}=1454 \mathrm{~m}^{2}$.

Eice $=334$; water energy heat of fusion from ice to water [KJoule $/ \mathrm{kg}$ ]

Evapor $=2256$; heat of vaporization $2256 \mathrm{KJ} / \mathrm{kg}$;

(2256-334)/100=19.22 for each temperature increase unit

$\mathrm{E}_{\text {water }+40 \mathrm{C}}=7402 \mathrm{~J} / \mathrm{mol} ;$ Eice $=6017.34 \mathrm{~J} / \mathrm{mol}$

The calculation energy change between frozen soil and flowing water with $+4^{0} \mathrm{C}$ could be following.

$7402+6017=13419 / 2=6709.5-681.75=6027.75 \mathrm{~J} / \mathrm{mol}$

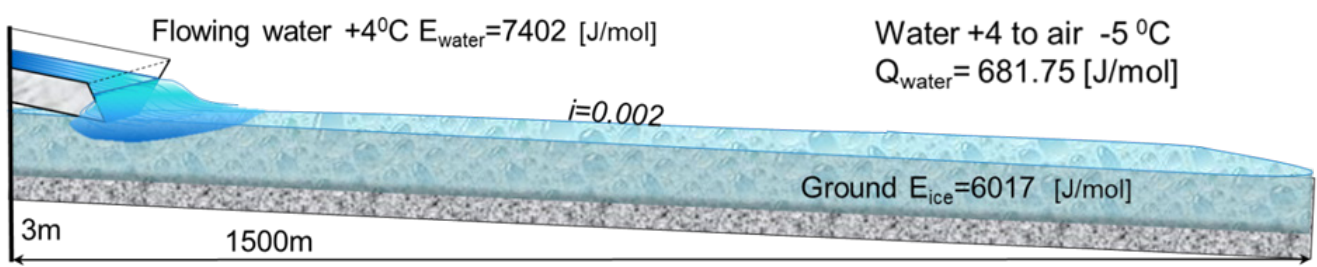

Figure 3. Energy change air and water flowing over frozen soil and ice

When decrease air temperature then increase energy transfer between air and flowing water, thus brings energy loss of water cause to create ice. The following table shows energy transfer between cold air and flowing water, which used in Matlab code for aufeis code.
The following program code show how to spread flowing water over ice sheet create next ice sheet. The air temperature decreases from $-50 \mathrm{C}$ until -30 0C. X and Y direction spread like ellipsoid and extending velocity and steps by law following formulas.

Darcy-Weissbachformula: $v=\sqrt{\frac{8 g}{\lambda}} \cdot \sqrt{R \cdot I}=C \cdot \sqrt{R \cdot I}=\frac{1}{n} \cdot R^{2 / 3} \cdot I^{1 / 2} ;$

where $\boldsymbol{c}$ - Chezy coefficient; $\boldsymbol{R}$ - Hydraulic radius; $\boldsymbol{I}$ - slope

$$
c=k_{s t} \cdot R_{h y}^{1 / 6}=\frac{1}{n} \cdot R_{h y}^{1 / 6} ; k_{s t}-\text { Strickler }\left[m^{1 / 3} / s\right] ; n-M a n n i n g\left[s / m^{1 / 3}\right] ;
$$

Gaukler-Manning-Strickler formula. $v=c \cdot \sqrt{R \cdot I}=\boldsymbol{k}_{s t} \cdot \boldsymbol{R}_{h y}^{2 / 3} \cdot \boldsymbol{I}^{1 / 2}$ where c- Chezy coefficient(1.3) 
In the study area, elevation difference between Eastern and Western boundary is $17 \mathrm{~m}$. In this area derivate surface water would be create Aufeis- ice sheet over ice until $-30^{\circ} \mathrm{C}$ when water discharge does not flow.

The extending velocity $\mathrm{x} ; \mathrm{y}$ in both directions widen by ellipsoidal way through slope under the Darcy Weissbach law. The length of this spreading velocity is estimated in following manner. After releasing, the $0.5 \mathrm{~m} 3$ water could occupy $19.08 \mathrm{~m}^{2}$ area of surface to create a film with a mol of $2.62 \mathrm{~cm}$ thickness. The velocity depends on the gradient.

See the following aufeis code after releasing:

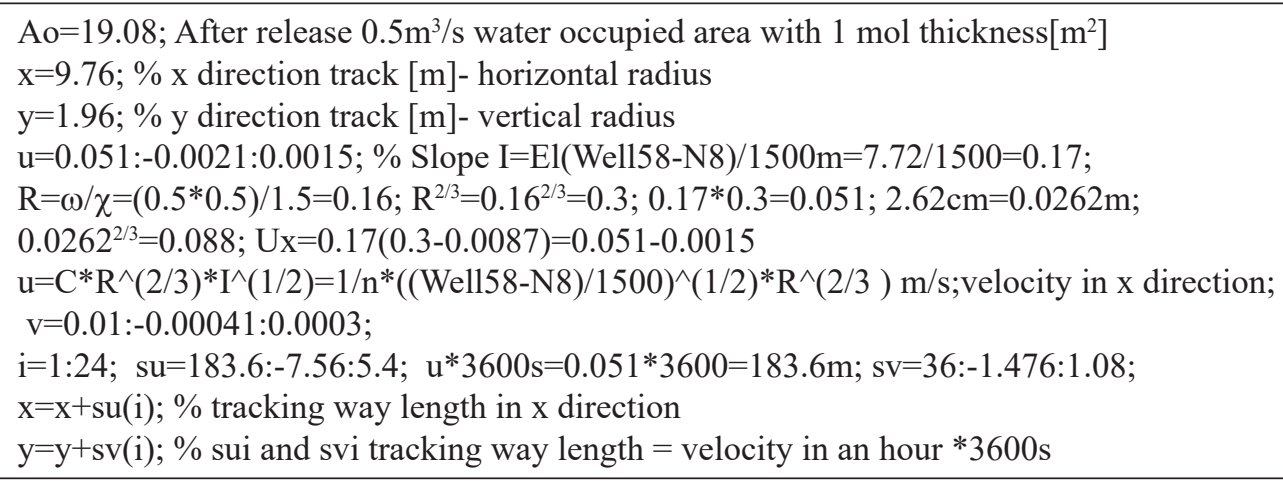

Such a way could estimate how spreading aufeis sheets over ice and how thickening it is depending on from air temperature.
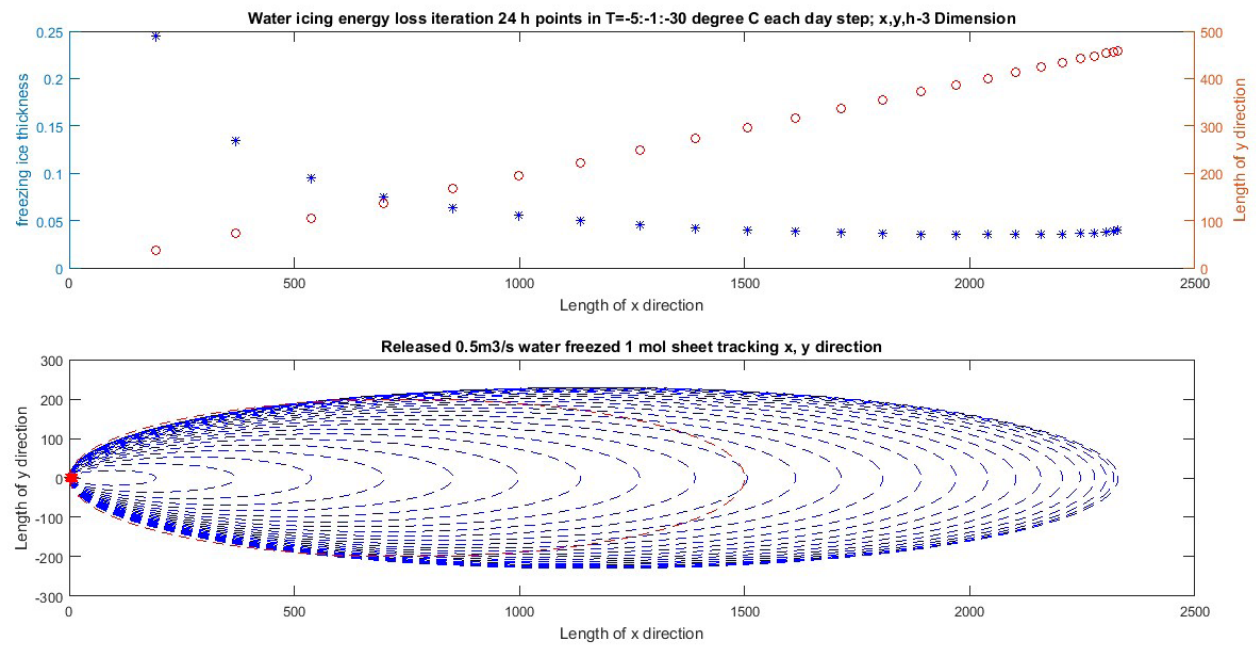

Figure 4. Aufeis generating in unlimited area with discharge $0.5 \mathrm{~m} 3 / \mathrm{s}$

The dynamics of this extending size of aufeis spreading over frozen ice sheets decrease while the air temperature drops dayby-day from $-5^{\circ} \mathrm{C}$ to $-30^{\circ} \mathrm{C}$. The result shows that the length of aufeis spreading is $2329 \mathrm{~m}$, $458 \mathrm{~m}$ wide and $1.54 \mathrm{~m}$ thick. The Matlab code for aufeis had simplified with tha same slope along a flat area.

In the following the next Matlab code presents the dynamics of aufeis extending when spreading water are courted with pipeline levees. The length of the levee is 1.5 
$\mathrm{km}$, which means that the ice storage is limited to an area of $1500 \mathrm{~m}$. See Figure 5.

The result shows that the length of aufeis spreading is $1500 \mathrm{~m}$, with a width of $400 \mathrm{~m}$ and a thickness of $2.72 \mathrm{~m}$, which is thicker than the unlimited area.

Both these aufeis ice storages are used for feflow simulation as melt water recharge in dry season when theTuul River dries out with no recharge from river side to the groundwater aquifer.

The icing code helps to store water source in ice form on surface which gives more storing volume then keeping water in reservoir by overflow dam because it can be stored like an ice hummock or icing.
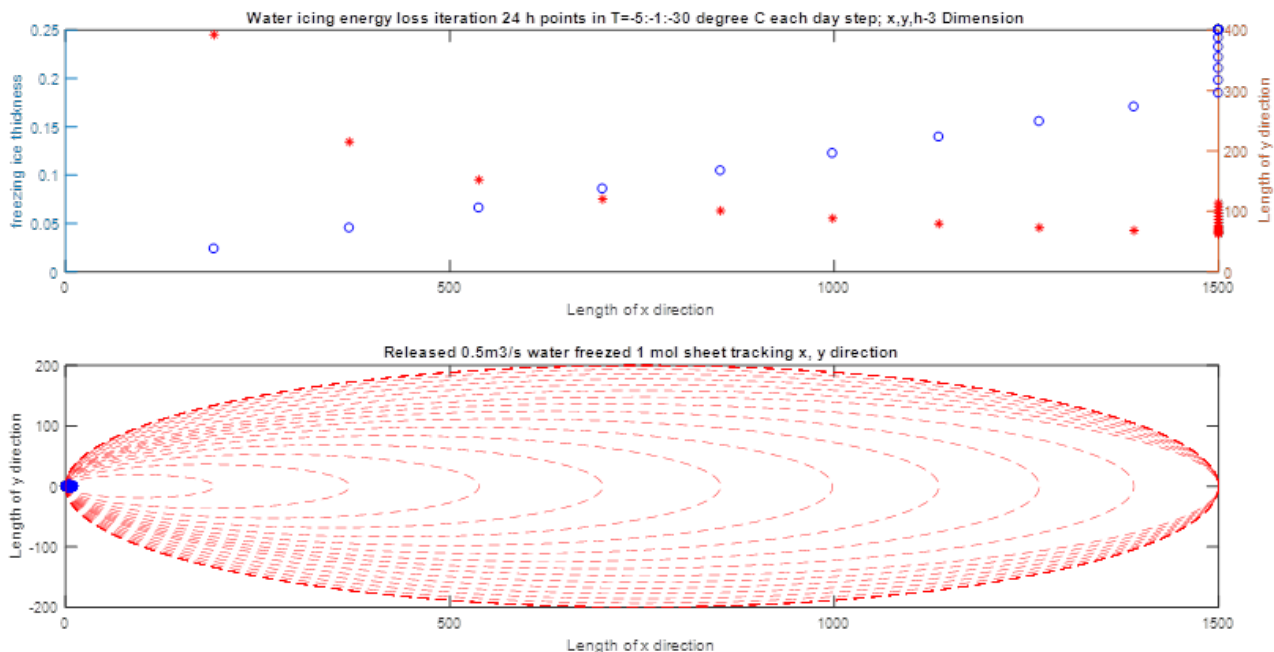

Figure 5. Aufeis generating in limited area with pipeline levees

These aufeis icings help us to store water through winter cold season bring it in dry season without loss and by the melting in dry season they recharge surface and groundwater until Tuul river surface has enough water to recharge and flow through the dry river bed. See figure 6 .

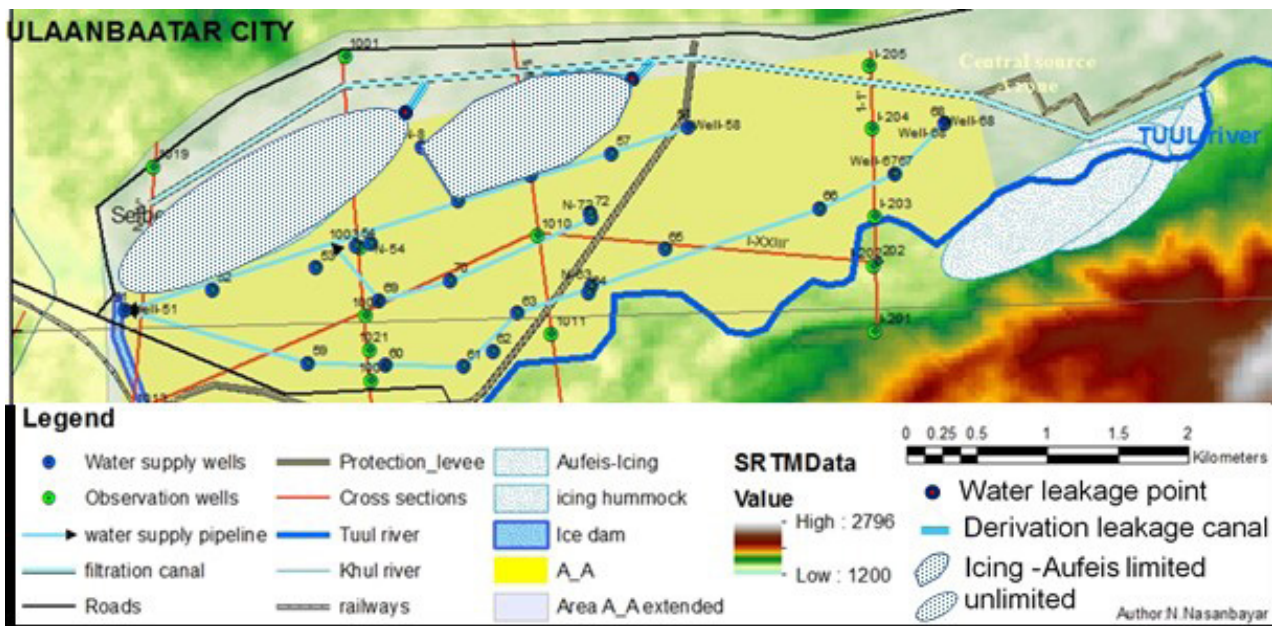

Figure 6. The water supply pipeline connecting wells to reservoir 
One of the possible managed aquifer recharge methods in a semi-arid, highly continental region is aufeis icing storage

\section{RESULTS AND DISCUSSION}

The ice creation for MAR application in feflow simulation

The creation of an artificial regime of Tuul River surface runoff through the redistribution of natural discharge, for an artificial groundwater recharge, makes it possible to be regulated in time and in area, which leads to a substantial increase in the exploitation reserves of groundwater and productivity of water intakes in Ulaanbaatar aquifer.

One of the artificial recharging groundwater resources is the temporary and spatial redistribution of surface runoff, which in the beginning of winter can create an ice formation. The surface runoff that flows over north side of the central section A-A zone through filtration channel, will release water at the end of the canal, which would then create ice sheets over ice sheets again and again. There are three types of promoting ice creation ways in the cold region in winter.

on the ground surface

in the underground open pit

on the river bed

The releasing of $1 \mathrm{~m}^{3} / \mathrm{s}$ water in the beginning of November until the middle of December creates icing when the average day temperatures are under $-5^{\circ} \mathrm{C}$.

The sensitivity analysis was carried out for feflow simulation to identify which parameter variation is more sensible to optimize simulation results and calibration. For a feflow model, some parameters for simulation run are different and it has been observed that the hydraulic conductivity of simulated parameter is more sensible to simulation results and measured groundwater level.

Hydraulic conductivity ratio was chosen for the calibration of simulated and measured values,. The calibration of hydraulic conductivity and determination of calculated hydrogeological parameters initial data for method that can be used for additional recharge FEFLOW simulation scenarios. the calculation of reserves. In the calibration used Microsoft Excel function - correl, dev sq average and mean squared deviation function. The feflow for a calibration simulated 162 times (see table 2)and for a validation 18 times. For a validation, used reverse validation method, which presents as changing small-simulated area to large area and ex boundary condition well monitored as for a validation.

The melting water from Aufeis begins to flow and recharge groundwater early April where surface water flows only until central source area and flows underground. Therefore, melt water from ice storage, recharge groundwater in central source A-A zone from north side from beginning of April until May where surface water flows until end of aquifer. See figure 8 .

Ice accumulation from November to end of December also recharge groundwater while water flows through drainage canal. Then it is transferred to an artificial regime with the subsequent supply of water to the canals, functioning together until the period of ice formation, provided the ice accumulation from surface water on the end of canal. From the following figure 8 seen that northern drainage canal allow us to accumulate $1 \mathrm{~m} 3 / \mathrm{s}$ flow water for a month from November to mid December 3.9 M.m3 water to store on surface. But with losses from evaporation and winter fog over frozen ice sheets also in melting season evaporation loss allowed only half of this quantity about 2 M.m3 to accumulate and recharge groundwater. The technical spatial opportunity, infrastructures gives us such a limited possibility and it is possible artificial recharging all of icing methods in the area. Also, is technical possible only until 5-10 m to digging and freezing ice and to create artificial permafrost wall.[5-6]. 
Table 3. Calibration and validation of feflow simulation

\begin{tabular}{|c|c|c|c|c|c|c|c|c|c|}
\hline \multirow{5}{*}{ 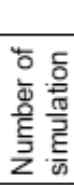 } & \multirow{5}{*}{\begin{tabular}{|c} 
Eastern BC \\
Western BC \\
$\begin{array}{c}\text { Monitoring } \\
\text { Wells }\end{array}$ \\
\end{tabular}} & \multirow{2}{*}{\begin{tabular}{|l|} 
Wells \\
$68-1327.7$ \\
\end{tabular}} & \multicolumn{3}{|c|}{ Correlation } & \multicolumn{4}{|c|}{ Average square dev Mean square deviation } \\
\hline & & & \multirow{4}{*}{ 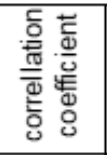 } & \multirow{4}{*}{ 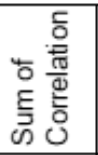 } & \multirow{4}{*}{ 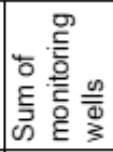 } & \multirow{4}{*}{ 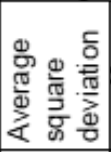 } & \multirow{4}{*}{ Sim of ASD } & \multirow{4}{*}{ 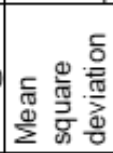 } & \multirow{4}{*}{ Sum of MSD } \\
\hline & & $51-1310.34$ & & & & & & & \\
\hline & & N8-1315.64 & & & & & & & \\
\hline & & $58-1321.76$ & & & & & & & \\
\hline \multirow{4}{*}{5} & \multirow{4}{*}{$293-12$} & №68 & 0.952 & & & 12.28 & & 24.10 & \\
\hline & & \begin{tabular}{|l} 
№51 \\
\end{tabular} & 0.890 & & & 7.74 & & 42.60 & \\
\hline & & N8 & 0.917 & & & 1.79 & & 29.76 & \\
\hline & & №58 & 0.923 & 3.682 & 1.840 & 3.16 & 24.97 & 37.74 & 134.20 \\
\hline \multirow{4}{*}{160} & \multirow{4}{*}{$330-40$} & №68 & 0.979605 & & & 10.78 & & 35.44 & \\
\hline & & №51 & 0.976686 & & & 15.83 & & 36.94 & \\
\hline & & N8 & 0.936719 & & & 7.03 & & 31.39 & \\
\hline & & №58 & 0.919286 & 3.812 & 1.856 & 8.03 & 41.67 & 50.95 & 154.71 \\
\hline \multirow{4}{*}{161} & \multirow{4}{*}{$293-4$} & №68 & 0.97675 & & & 10.71 & & 35.18 & \\
\hline & & \begin{tabular}{|l}
$№ 51$ \\
\end{tabular} & 0.95565 & & & 14.79 & & 35.73 & \\
\hline & & N8 & 0.913528 & & & 6.62 & & 33.58 & \\
\hline & & №58 & 0.907703 & 3.754 & 1.821 & 7.69 & 39.81 & 50.91 & 155.40 \\
\hline \multirow{4}{*}{162} & \multirow{4}{*}{ 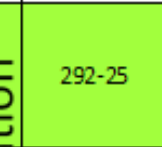 } & №68 & 0.972978 & & & 10.22 & & 34.65 & \\
\hline & & \begin{tabular}{|l|} 
№51 \\
\end{tabular} & 0.97307 & & & 14.67 & & 35.62 & \\
\hline & & N8 & 0.840523 & & & 5.80 & & 31.41 & \\
\hline & & №58 & 0.835059 & 3.622 & 1.676 & 6.72 & 37.41 & 49.75 & 151.43 \\
\hline \multirow{4}{*}{170} & \multirow{4}{*}{$\begin{array}{c}330-30 \\
/ 1305.5- \\
132326\end{array}$} & №68 & 0.979467 & & & 10.63 & & 35.11 & \\
\hline & & \begin{tabular}{|l} 
№51 \\
\end{tabular} & 0.971521 & & & 48.05 & & 78.16 & \\
\hline & & N8 & 0.900138 & & & 6.69 & & 29.59 & \\
\hline & & №58 & 0.901302 & 3.635 & 1.856 & 7.15 & 72.51 & 48.78 & 191.64 \\
\hline \multirow{4}{*}{176} & \multirow{4}{*}{$\begin{array}{c}500-40 \\
/ 1305.5- \\
132326\end{array}$} & №68 & 0.987448 & & & 11.28 & & 35.70 & \\
\hline & & \begin{tabular}{|l|} 
№51 \\
\end{tabular} & 0.972535 & & & 50.75 & & 83.71 & \\
\hline & & N8 & 0.952723 & & & 9.19 & & 3204 & \\
\hline & & №58 & 0.921597 & 3.635 & 1.856 & 8.88 & 80.10 & 47.71 & 199.15 \\
\hline
\end{tabular}
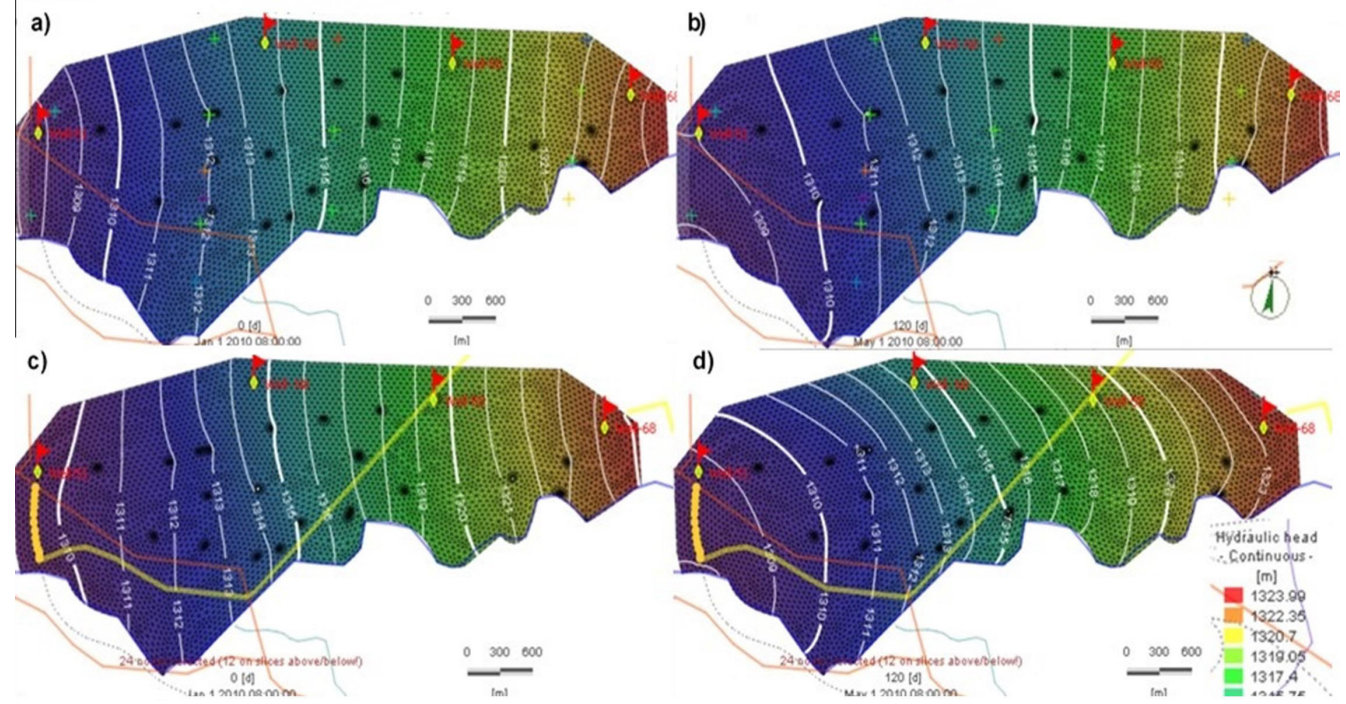

Figure 8. Groundwater contour compared figures in natural vs MAR conditions

a) Groundwater level in natural condition 01 Jan.; b) 01 May; c) MAR condition 01 Jan.; d) 01 May. 2010 
Aufeis, icing method brings more recharging water in the middle of the study area and its other constituent subsections, and an ice wall increases the backside of the western boundary. The drainage canal filtrates through the northern side and the recharge occupies an entire area from the east to the western boundary.

The combination method includes an ice wall, icing and a drainage canal. The drainage canal filtrates water from east to west along the northern side of the study area and the water released fromthe rest of the area in early winter creates icing, after which the drainage canal filtration ceases altogether.

As can be seen in Figure 9, recharge from the drainage canal begins in May and ends in November, with icing recharge beginning in the middle of March continuing until May, and the ice wall, holding groundwater at the back, continues from March until November. The red line represents the groundwater level in manually measured value, the silver blue lines represent the simulation results. The compared graph shows that an ice wall built along the entirety of the western boundary increases groundwater levels more along its back side as well as in combination with a short ice wall. (See Figure 9). When an ice wall is combined with the northern drainage canal it recharges more water, to the amount of $945 \mathrm{~T} . \mathrm{m}^{3}$. In the northern drainage canal, combined with groundwater flux retarded by an ice wall, the level of groundwater along the back of the ice wall increases and holds about 429 T.m ${ }^{3}$ of additional water. Aufeis is an icing method bringing more recharging water in the middle of the study area for its other constituent subsections, and an ice wall increasing the backside of western boundary. The drainage canal filtrates through the northern side of the study area and recharge occupies the entire area from the eastern to the western boundary.

The entire combination method includes an ice wall, icing and a drainage canal. In this scenario the drainage canal filtrates water from east to west along the north side of the study area and the rest is released as early winter creates icing. Thus, this icing method performs well after drainage canal filtration ceases altogether.

As can be seen in the following figure, recharge from the drainage canal begins in May and ends in November, with icing recharge beginning in the middle of March and lasting until May, and the ice wall holding groundwater from March until November.

A preliminary analysis, as presented in this study, was done to identify low-cost MAR implementation measures adapted to the specific natural conditions of Northern Mongolia. Thus, the coldness of the winter weather can be used to keep the water in an ice form as well as a water resource in the winter season and which can be used during low flow dry season by melting ice where rivers have dried out. In nature, we can reserve more water in ice form as Aufeis to help build some hydraulic structures such as a drainage canal or underground dam. Both these structures can help build underground water stores and also maintain them on the surface in an ice form. Taking advantage of the cold and the icing in a semi-arid, highly continental region such as Mongolia can increase groundwater resources. Non-conventional artificial recharging methods like those discussed in this dissertation, such as ice storage, helps groundwater recharge in dry season, when there is no flow and the river beds become dry. Surface water naturally accumulates from October to December and is kept in ice form from river flow in the semi-arid, highly continental region, such the study area. During the subsequent dry season, these sources increase and the availability of potential recharge water improves by the melting water sources, such as icing.

One of the possibilities to preserve water resources is to keep water in the ice form by regulating groundwater flux control in highly continental cold region to eleminate dry river beds and by maintaining primary source rivers, such as the Tuul River, where there is continuous recharge during low flow seasons 


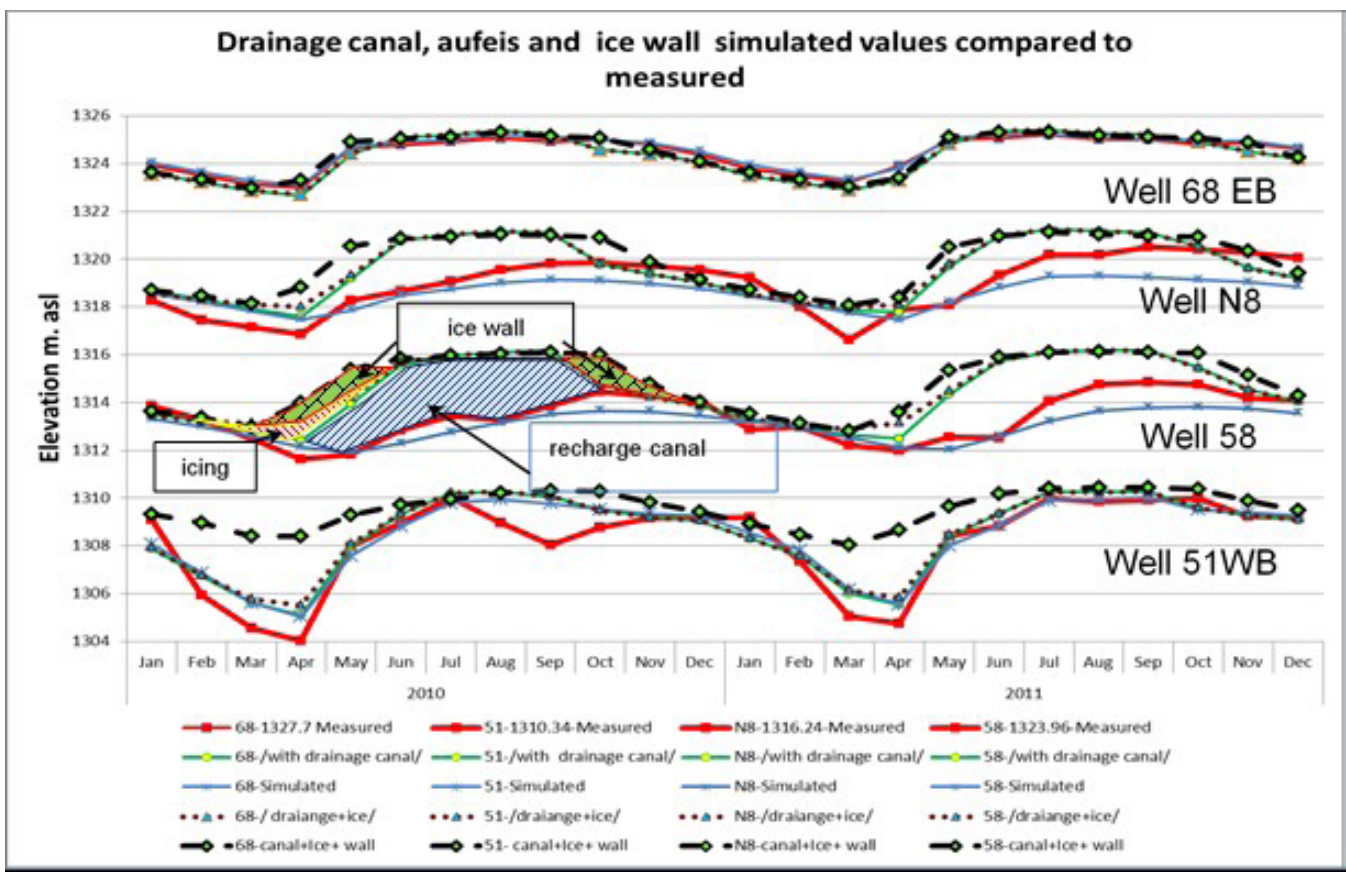

Figure 9. Variationariation combinations in simulated area compare to measured groundwater level

caused by melting ice blocks.

The Aufeis blocks, icing made in river valley increases inner continental cycle by evaporating melt water. This helps vegetation to grow and increases precipitation during the dry season. In autumn, from September

\section{CONCLUSIONS}

The result of feflow simulation in each MAR method scenarios demonstrates the following results:

- Single ice wall on western boundary alone under natural condition without drainage canal increases ground water resources by $516 \mathrm{~T} . \mathrm{m}^{3} /$ year.

- The drainage canal through northern side filtrates groundwater at around $1 \mathrm{M} \cdot \mathrm{m}^{3} /$ year.

- The icing at the end of drainage canal recharges groundwater resources in aquifer by $1.6 \mathrm{M} \cdot \mathrm{m}^{3}$ water

Additional recharge of groundwater quantity of all combined MAR methods is to October, soil moisture increases with more rain during this period while in spring (March to April) there is more humidity in the air and more rain. Meltwater is the main source for the continuous flow of rivers and for the recharging of groundwater aquifers.

\section{$2.55 \mathrm{M} . \mathrm{m}^{3} /$ year.}

The following can be safely concluded basing on the results of this analysis:

Icing or Aufeis keeps water in ice form starting from end of rainy season through to the dry season of winter and increases groundwater sources by melting.

Around the icing area, naturally grown bushes and trees as well as designed recreation areas could renature the environment for the local population.

A positive side effect of increased evaporation from the open water springs is that air humidity will be increased which will lead to artificial precipitation and a deposition 
of atmospheric particles from air pollution and thus help improve air quality in the city and its surroundings

This MAR method of storing water in an ice form in a semi-arid, cold, highly continental region could help produce water [3] during the dry season, which would increase the inner continental hydrologic cycle by melting and evaporation. In dry season ice melt evaporates and increases precipitation. Some northern lakes, such as Khovsgol exhibit ice cover that breaks up in the middle of June, and so the ice blocks, several meters thick created by Aufeis, would not melt for sometime, which could become an important source of fresh water at lands lying at lower elevation. Every year during dry season many forest fires occur in Mongolia, at least partially due to no precipitation and lower air humidity. Therefore, ice-keeping methods would help us keep the environment green, and they are environmentally close to natural process to improve human and natural habitats. 


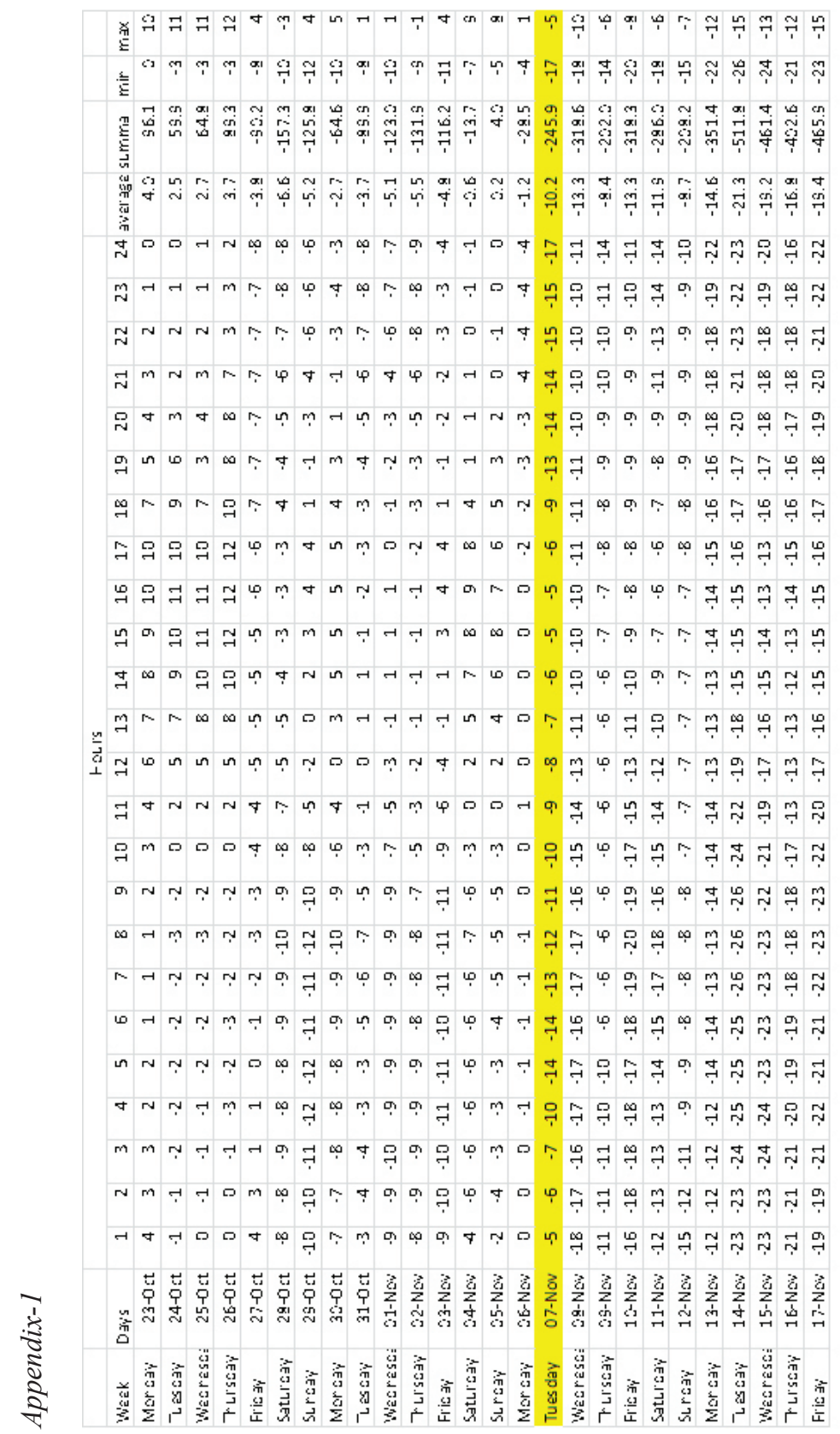

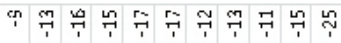
ๆ

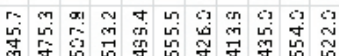

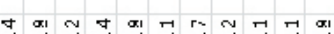
गें क्षं

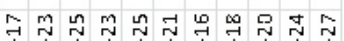

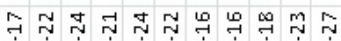

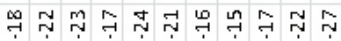
ชด 寻只 ำ

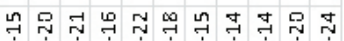

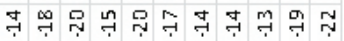

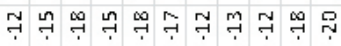
ำ

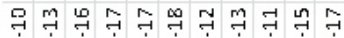
ด. ำ 눈

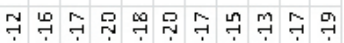

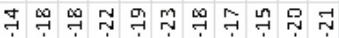

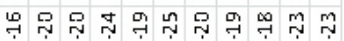
ๆิ 구규ำ ๑ ๑ึ

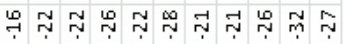
กี

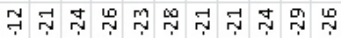

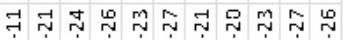

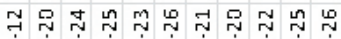

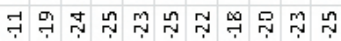

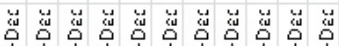

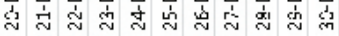

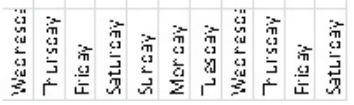




\section{REFERENCES}

[1] Ashton, G. D., Deterioration of Floating Ice Covers, J. Energy Resour. pp. 177-182, 1985.

[2] Batima Punsalmaa, Batnasan Nyamsüren, Bolormaa Buyndalai, (2004). Trends in River and Lake Ice in Mongolia. AIACC Working Paper No. 4.

[3] Robin Grayson, (2010) Asian Ice Shields and Climate Change World Placer Journal-2010. Volume 10, pp. 21-45.

[4] Davaa Gombo, Erdenetuya Magsar, Hydrological Changes in the Upper Tuul River Basin (2004). Institute of Meteorology and Hydrology, Information and Computer Centre, Juulchni St. 5, Ulaanbaatar-46, Mongolia.

[5] Davaa, G., (2008), Surface Water Resources in Mongolia.

[6] Dashjamts, D., (2013) Geotechnical Problems of Construction on Permafrost in Mongolia, Sciences in Cold and Arid Regions, 5(5): 0667-0676.

[7] Dashjamts. D., (2015). Permafrost and Geotechnical Investigations in Nalaikh Depression of Mongolia [J]. Sciences in Cold and Arid Regions, 7(4): pp. 438-455.

[8] Froehlich, Wojciech; Slupik, January, (1982). French, H. M., ed. "River Icings and Fluvial Activity in Extreme Continental Climate: Khangai Mountains, Mongolia" (PDF).

[9] GIM- Geo-ecology Institute Mongolia (1997): The research work report of Tuul River water Reserves Decreases Reason, Protection, Provision of UB. -

[10] GIM - Geoecology Institute of Mongolia (1999): "Ecological Assessment of Tuul River" Report, Ulaanbaatar.

[11] GIM - Geoecology Institute of Mongolia (2010): The Report of Water Quality, Aquatic Environmental Ecology Study,

[12] George, D. Ashton, Thin Ice Growth, Water Resources Research,Vol. 25(3), po. 564-566, March 1989.

[13] IMHM - Institute of Meteorology and Hydrology Mongolia. (1986-2006). Weather Parameters Data of Ulaanbaatar.

[14] Kresic, N., (2006). Hydrogeology and groundwater modeling. CRC Press, S. 807.

[15] Kimrey, J. O., Artificial Recharge of Groundwater and its Role in Water Management

[16] Kuroda, T., Rate Determining Processes of Sea Ice Growth, Ann. Glaciol., pp. 6, 168-170, 1985.

[17] L. Emerton, N. Erdenesaikhan, B. de Veen, D. Tsogoo, L. Janchivdorj, P. Suvd, B. Enkhtsetseg, G. Gandolgor, Ch. Dorjsüren, D. Sainbayar and A. Enkhbaatar, (2010). The Economic Value of the Upper Tuul Ecosystem, Mongolia.

[18] Maki Tsujimura, Koichi Ikeda, Tadashi Tanaka, Lünten Janchivdorj, Badamgarav Erdenchimeg, Damdinbazar Önörjargal, Ramasamy Jayakumar (2013): Groundwater and Surface Water Interactions in an Alluvial Plain, Tuul River Basin, Ulaanbaatar, Mongolia. Sciences in Cold and Arid Regions, pp. 126-132.

[19] Mongolian Climate and Surface Water Reserve Atlas (1985) Ulaanbaatar.

[20] SIWRMM "Strengthening Integrated Water Resources Management in Mongolia" Project. Tuul River Basin Integrated Water Resources Management Assessment Report. (2012).

[21] RIBES-Research Institute on Building Engineering Studies. (1979):Technical Report of Engineering Survey TOM-2 . Moscow.

[22] Reddy, K. R., (2008). Enhanced Aquifer Recharge: Over-exploitation and Contamination of Shared Groundwater Resources, Springer Netherlands.

[23] S. Zandaryaa, U. Borchuluun, Sh. Mönkhtuya, Reserves, Consumption and Contamination of Groundwater in Ulaanbaatar, Mongolia. Atlas of Urban Geology. 2003. Volume 14. pp. 446-476.

[24] SIWRMM - Strengthening Integrated Water Resource Management In Mongolia Project. (2013): Groundwater Model for UB. iMOD

[25] SIWRMM. Tuul River Basin Integrated Water Resources Management Assessment Report. 2012 11, Ulaanbaatar Mongolia.

[26] Önörjargal, D., Bayarmaa, P., (2009). The Characteristics of the Quaternary Aquifer in the Tuul 
River Basin. UNESCO Chair Workshop on Sustainable Groundwater Management in Arid and Semi-arid Regions. PP. 51-56.

[27] Ulaanbaatar City Master Plan 2020, Development Policy 2030. (2014).

[28] Baldandorj, Ts. and others, (2000), Concept for Further Development, Water Resource, Location and Current Situation of Drinking and Industrial Water Supply in Ulaanbaatar City. Ulaanbaatar. (In Mongolian). 